Journal of Animal and Veterinary Advances 9 (7): 1137-1142, 2010

ISSN: $1680-5593$

(C) Medwell Journals, 2010

\title{
Effects of Hanging Ratio on Gill Net Selectivity for Annular Sea Bream (Diplodus annularis) in the Northern Aegean Sea, Turkey
}

\author{
Adnan Ayaz, Ugur Altinagac, Ugur Ozekinci, Ozgur Cengiz and Alkan Oztekin \\ Faculty of Fisheries, Canakkale Onsekiz Mart University, Canakkale, Turkey
}

\begin{abstract}
This study has been conducted in the North Aegean Sea around the coasts of the Gallipoli peninsula at 3-30 m of water depth between February 2007 and June 2009. In order to test the effect of the hanging ratio on the selectivity, 9 gillnets with 3 different hanging ratios $(E=0.4-0.6)$ and 3 different mesh sizes (18-20-22 mm) have been made use of. Other than, the hanging ratios and mesh size all other features and specifications of gill nets were identical. Select method was used to fit gillnet selectivity curves. A total of 64 fishery operations have been performed in the study. The lognormal model gave the best fit for all hanging ratios (for hanging ratio $(E)=0.4-0.6$, the model deviance $=138.9,66.19,56.23$, respectively). It was determined that there was no significant selectivity differences among the same mesh size for different hanging ratios. The results showed that there is no effect of hanging ratios on size selectivity of annular sea bream (Diplodus annularis L.) in north Aegean gillnet fishery.
\end{abstract}

Key words: Annular sea bream, gillnet selectivity, select method, hanging ratio, Northern Aegean Sea

\section{INTRODUCTION}

For sustainable fishery purpose knowing of the selectivity of the fishing gear is important for the protection of young individuals and the development of appropriate management policies. In parallel to this gillnets are the most frequently used fishing gear because of ease of their use, their low costs and high selectivity (Holt, 1963; Hamley, 1975; Reis and Pawson, 1992; Metin et al., 1998; Kara, 2003). It has been reported that the net mesh size, body shape, fish size, hanging ratio, the thickness and the flexibility of the netting twine, the visibility of the twine, fish behaviour affect the selectivity of gill nets (Clarke, 1960; Hamley, 1975). However, it has been stated expressly that the major factor affecting the selectivity is the mesh size (Von Brandt, 1975).

For this reason, the studies on selectivity have mostly focused on the effect of mesh size on the size selectivity (Van Densen, 1987; Karunasinghe and Wijeyaratne, 1990; Pet et al., 1995; Santos et al., 1995; Petrakis and Stergiou, 1996; Psuty and Borowski, 1997; Santos, 1998; Madsen et al., 1999; Purbayanto et al., 2000; Fujimori and Tokai, 2001; Lucena and O'Brien, 2001; Fabi et al., 2002; Stergiou and Erzini, 2002; Park et al., 2004; Fonseca et al., 2005; Ozekinci, 2005; Askey et al., 2007; Revill et al., 2007; Karakulak and Erk, 2008; Ayaz et al., 2009; Prchalova et al., 2009). There have been a low number of publications on the effects of other factors on selectivity. These studies focused on the effect of seasonal variations (Moth-Poulsen, 2003), the twine thickness (Yokota et al., 2001; Holst et al., 2002) and the hanging ratio on selectivity (Balik and Cubuk, 2001). Moth-Poulsen (2003) has stated that the effect of seasonal changes is considerable on selectivity. Holst et al. (2002) have stated that the twine thickness affects the catch efficiency but it has little effect on the selectivity. Similarly, Yokota et al. (2001) found that the effect of the twine thickness has no effect on selectivity. However, they have reported a positive correlation between the twine thickness and the mesh opening and also emphasized that this could be important in selectivity. In the studies where the effect of hanging ratio on selectivity were investigated, a significant findings stating the effect of hanging ratio on selectivity could not be attained (Sulaeman et al., 2000; Balik and Cubuk, 2001).

In this study, the effect of different hanging ratios on the size selectivity of annular sea breams (Diplodus annularis L.) caught in gill nets located in the Northern Aegean Sea were investigated.

\section{MATERIALS AND METHODS}

This study had been conducted in the Northern part of Aegean Sea, around the coasts of the Gallipoli Peninsula at 3-30 $\mathrm{m}$ of water depth between February 2007 and June 2009 (Fig. 1). In order to test the effect of the hanging ratio on the selectivity, 9 gillnets with 3 different hanging ratios $(E=0.4-0.6)$ and 3 different mesh sizes $(18-20-22 \mathrm{~mm})$ have been made use of. The other specifications of the nets were kept the same except for the hanging ratio and the mesh size. Two of the three hanging ratios $(\mathrm{E}=0.4-0.5)$ are being massively used in the nets by the fishermen fishing along the North Aegean

Corresponding Author: Ozgur Cengiz, Faculty of Fisheries, Canakkale Onsekiz Mart University, Canakkale, Turkey 


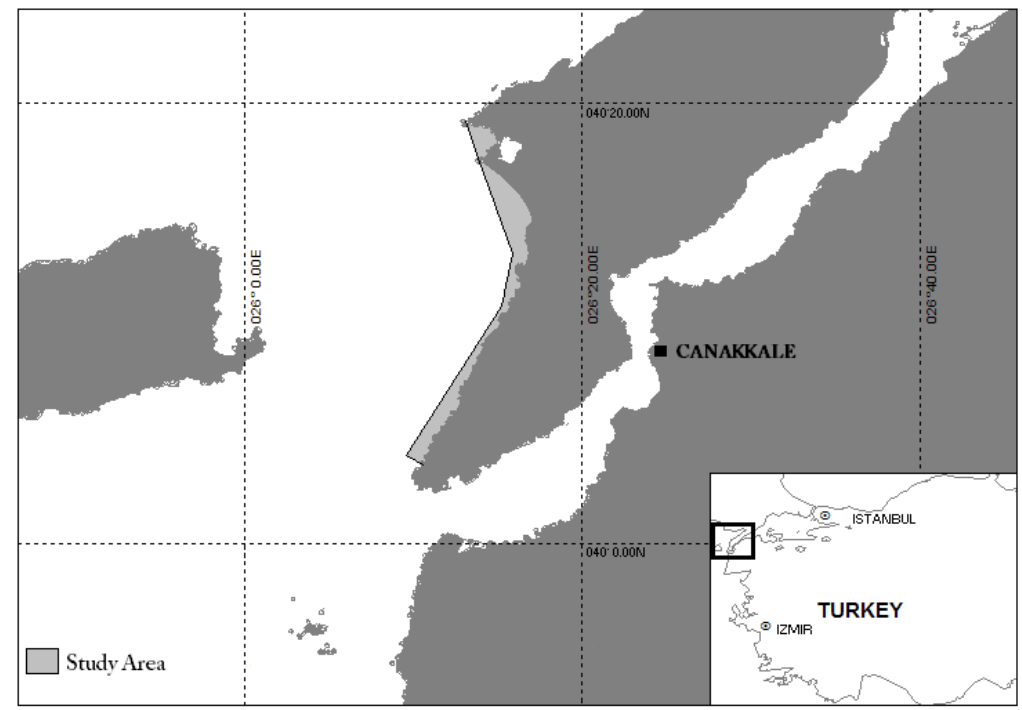

Fig. 1: Study area

were carried out in total. The total length distributions of fish caught by nets were recorded. Length measurements of caught fish were made in mm sensitivity. The mesh sizes corresponding to each hanging ratio were analyzed among themselves in selectivity calculations. The select method has been used in the selectivity calculations (Millar, 1992; Millar and Holst, 1997; Millar and Fryer, 1999). The standard selectivity program GILLNET (Generalized Including Log-Linear N Estimation Technique) has been used to estimate the selectivity parameters of the nets (CONSTANT, 1998). Using this program, it is possible to calculate the selectivity curve parameters using five different models normal location, normal scale, lognormal, gamma and bi-normal methods. Two criteria have been taken into consideration in the determination of the selectivity curve of the suitable model.

The first one is the smallest deviance and the second one is the p-value displaying the degree of model compatibility which was set to the critical value of 0.05 . In order to compare the results obtained at different hanging ratios for the same mesh size, Microsoft Excel has been used. The selectivity curves of the suitable model which have been obtained from GILLNET have been overlaid in Microsoft Excel. One-way ANOVA has been used to investigate the significance of the variation in the fish total size distributions among the trial nets of the same mesh size and varying hanging ratios.

\section{RESULTS AND DISCUSSION}

Sixty four fishery operations have been performed in the study. About 902 annular sea breams were caught in
Table 1: Number annular sea bream captured by experimental nets

\begin{tabular}{lcrcr}
\hline & Nominal bar length $(\mathrm{mm})$ & & \\
Hanging ratio & \multicolumn{1}{c}{-18} & 20 & 22 & Total \\
\hline 0.4 & 108 & 118 & 117 & 343 \\
0.5 & 62 & 98 & 104 & 264 \\
0.6 & 80 & 109 & 106 & 295 \\
Total & 250 & 325 & 327 & 902 \\
\hline
\end{tabular}

the trials and the most fish ( 327 fish) were caught using the $22 \mathrm{~mm}$ mesh size nets (Table 1). Based on the selectivity parameters which have been calculated by the GILLNET software, the lognormal model which yielded the lowest model deviance for all hanging ratios has been selected as the best model (for $\mathrm{E}=0.4-0.6$, the model deviance $=138.9,66.19,56.23$, respectively) (Table 2). The calculated model lengths and spread values were shown in Table 3 .

The model lengths and spread value were observed to increase with increasing mesh size (Table 3). The frequency distributions (\%) and selectivity curves with respect to the variations in twine thickness in the trial nets were shown in Fig. 2 and 3.

The difference in variation of the total fish length distribution at the same mesh size and at different hanging ratios were found insignificant according to the results of the selectivity curves and the one-way ANOVA test $(p>0.05)$.

The differences among the catch efficiencies of the nets were also identified as insignificant $(p>0.05)$. In this study, no statistically significant differences have been observed among the length selectivity or the catch efficiency of the fish caught using nets with the same 
Table 2: Result of select method for the estimation of gillnet selectivity for different hanging ratios

\begin{tabular}{|c|c|c|c|c|c|c|c|c|c|}
\hline Spec. & Model & $\begin{array}{l}\text { Equal fishing } \\
\text { power parameters }\end{array}$ & M. Dev. & $\mathrm{p}$ & $\begin{array}{l}\text { Fishing power } \\
\text { mesh size parameters }\end{array}$ & M. Dev & $\mathrm{p}$ & df & $\begin{array}{l}\text { Hang } \\
\text { ratio }\end{array}$ \\
\hline Annular & Normal scale & $(\mathrm{k} 1, \mathrm{k} 2)=0.28169,0.02640$ & 172.28 & 0.0000 & $(\mathrm{k} 1, \mathrm{k} 2)=0.28416,0.02628$ & 172.48 & 0.0000 & 34 & 0.4 \\
\hline Sea & Normal location & $(\mathrm{k}, \mathrm{s})=0.27987,1.02263$ & 158.47 & 0.0000 & $(\mathrm{k}, \mathrm{s})=0.28221,1.02669$ & 156.94 & 0.0000 & 34 & \\
\hline Bream & Log normal & $(\mathrm{m}, \mathrm{s})=2.3143,0.08702$ & 138.9 & 0.0000 & $(\mathrm{~m}, \mathrm{~s})=2.32187,0.08702$ & 138.9 & 0.0000 & 34 & \\
\hline (Diplodus & Gamma & $(\mathrm{k}, \mathrm{a})=0.00222,126.79809$ & 149.17 & 0.000 & $(\mathrm{k}, \mathrm{a})=0.00222,127.79809$ & 149.17 & 0.0000 & 34 & \\
\hline \multirow[t]{10}{*}{ annularis) } & Bi-modal & No fit & & & No fit & & & & \\
\hline & Normal scale & $(\mathrm{k} 1, \mathrm{k} 2)=0.28155,0.02501$ & 90.24 & 0.0000 & $(\mathrm{k} 1, \mathrm{k} 2)=0.28377,0.02491$ & 90.37 & 0.0000 & 32 & 0.5 \\
\hline & Normal location & $(\mathrm{k}, \mathrm{s})=0.27952,0.95028$ & 78.5 & 0.0000 & $(\mathrm{k}, \mathrm{s})=0.28152,0.95328$ & 78.29 & 0.0000 & 32 & \\
\hline & Log normal & $(\mathrm{m}, \mathrm{s})=2.31554,0.08069$ & 66.19 & 0.0000 & $(\mathrm{~m}, \mathrm{~s})=2.32206,0.08069$ & 66.19 & 0.0004 & 32 & \\
\hline & Gamma & $(\mathrm{k}, \mathrm{a})=0.00194,145.35542$ & 73.59 & 0.0000 & $(k, a)=0.00194,146.35542$ & 73.59 & 0.0000 & 32 & \\
\hline & Bi-modal & No fit & & & No fit & & & & \\
\hline & Normal scale & $(\mathrm{k} 1, \mathrm{k} 2)=0.28097,0.02417$ & 74.34 & 0.0000 & $(\mathrm{k} 1, \mathrm{k} 2)=0.28305,0.02408$ & 74.44 & 0.0000 & 28 & 0.6 \\
\hline & Normal location & $(\mathrm{k}, \mathrm{s})=0.27864,0.94260$ & 68.1 & 0.0000 & $(\mathrm{k}, \mathrm{s})=0.28063,0.94546$ & 67.94 & 0.000 & 28 & \\
\hline & Log normal & $(\mathrm{m}, \mathrm{s})=2.31197,0.08135$ & 56.23 & 0.0000 & $(\mathrm{~m}, \mathrm{~s})=2.31859,0.08135$ & 56.23 & 0.0012 & 28 & \\
\hline & Gamma & $(\mathrm{k}, \mathrm{a})=0.00192,146.39032$ & 61.83 & 0.0002 & $(\mathrm{k}, \mathrm{a})=0.00192,147.39032$ & 61.83 & 0.0002 & 28 & \\
\hline
\end{tabular}

Table 3: Model length and spread values for the best fitting models of gillnet selectivity model

\begin{tabular}{lrrrl}
\hline \multicolumn{5}{c}{ Hanging ratio } \\
Mesh size & \multicolumn{1}{c}{0.4} & 0.5 & 0.6 & Model \\
\hline $18 \mathrm{~mm}$ & & & & \\
Modal length & 10.110 & 10.640 & 10.090 & Log normal \\
spread & 0.892 & 0.821 & 0.830 & \\
$20 \mathrm{~mm}$ & & & & \\
Modal length & 11.240 & 11.180 & 11.210 & Log normal \\
spread & 0.991 & 0.912 & 0.923 & \\
22 mm & & & & \\
Modal length & 12.360 & 12.300 & 12.330 & Log normal \\
spread & 1.090 & 1.003 & 1.015 & \\
\hline
\end{tabular}

mesh size and differing hanging ratios. Balik and Cubuk (2001) have supported these findings. The effects of hanging ratio have been found significant on the catch efficiency in recent studies (Samaranayaka et al., 1997; Balik and Cubuk, 2001; Gray et al., 2005). In the present study, it was expected to have a negative correlation between the hanging ratio and the spreading of the curves and for the nets with small hanging ratios to have higher catch efficiencies.

Although, the mesh size curves for the hanging ratio $\mathrm{E}=0.4$ were as expected, they were not as expected for the hanging ratios $\mathrm{E}=0.5$ and 0.6 . Sulaeman et al. (2000) has reported that the spreading of the curves increased with decreasing hanging ratio. The body form of the fish and the hanging ratio which are among the factors affecting selectivity (Clarke, 1960; Hamley, 1975) were thought to be so by being interactive themselves because as the hanging ratio decreased, the tension of the net decreased and therefore the chance of the fish getting caught in the net increased (Sulaeman et al., 2000).

Because the annular sea bream did not have any morphological structures other than the fin rays which would cause them to get tangled in the net, the hanging ratio was considered not to affect the selectivity and the

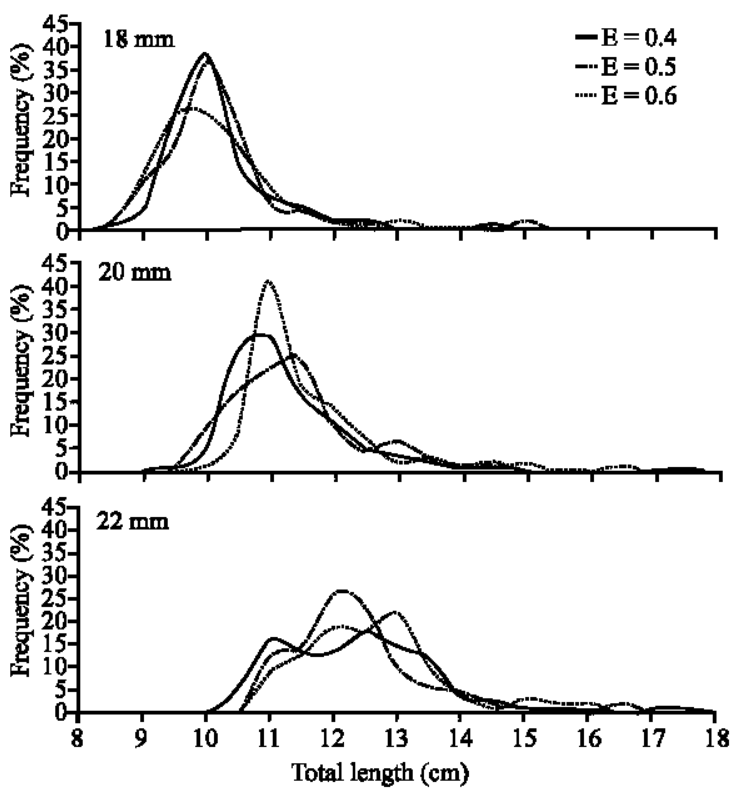

Fig. 2: Frequency distribution (\%) of different hanging ratios and mesh sizes for annular sea bream

catch efficiency. The model length was determined as 9.97-12.52 cm for 18-20-22 mm mesh size in various studies conducted using gillnets (Petrakis and Stergiou, 1995; Metin et al., 1998; Stergiou and Erzini, 2002; Stergiou and Karpouzi, 2003; Karakulak and Erk, 2008). The lengths of the fish which have been caught in the nets that have been used in the study were also within the provided range.

The length of annular sea bream at initial reproduction were determined as $13 \mathrm{~cm}$ in the western parts of the Mediterranean Sea (Fischer and Schneider, 1987; Froese and Pauly, 2006), $13 \mathrm{~cm}$ for the southern coasts of Portugal (Santos, 1998) and 10-10.5 cm (femalemale) for the Aegean Sea and it has been recommended 


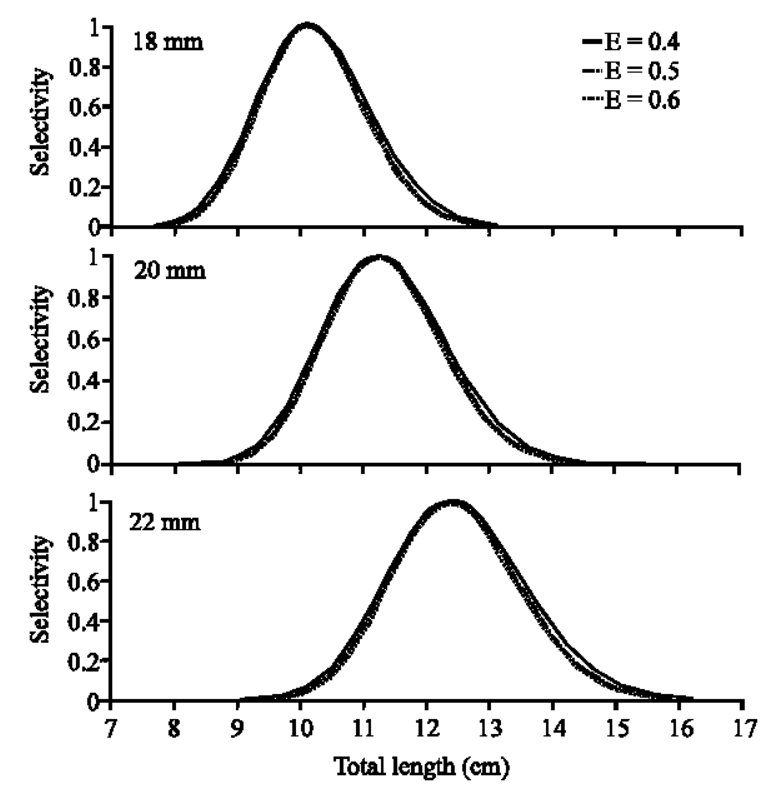

Fig. 3: Selectivity curves of different hanging ratios and mesh size for annular sea bream

that fish that were $<11 \mathrm{~cm}$ of total length should not be caught (Kinacigil et al., 2008). Metin et al. (1998) have proposed the use of nets having $22 \mathrm{~mm}$ mesh size or more in the catching of annular sea bream. Similarly in the study, it has been detected that fish which have not yet achieved their initial reproduction lengths were caught in high ratios in the nets with mesh sizes $<22 \mathrm{~mm}$. This result supports Metin et al. (1998).

\section{CONCLUSION}

In the present study, it has been observed that the hanging ratio was not effective on selectivity. However, it is known that as the hanging ratio decreased fish being caught in the net becomes more tangled as a result of the elastic stretching of the net getting decreased. Low hanging ratio may be effective on selectivity of fish which morphologically more available to tangle. This case related with fish morphology is important for fisheries management.

\section{ACKNOWLEDGEMENTS}

This study was supported by the Scientific and Technological Research Council of Turkey (TUBITAK Project number: 106Y021). We render thanks to the ship staff Cahit Ceviz and Aytaç Altin spending effort for this study.

\section{REFERENCES}

Askey, P.J., J.R. Post, E.A. Parkinson, E. Rivot, A.J. Paul and P.A. Biro, 2007. Estimation of gillnet efficiency and selectivity across multiple sampling units: A hierarchical Bayesian analysis using mark-recapture data. Fish. Res., 83: 162-174.

Ayaz, A., S. Kale, O. Cengiz, U. Altinagac, U. Ozekinci, A. Oztekin and A. Altin, 2009. Gillnet Selectivity for Bogue Boops boops caught by drive-in fishing method from Northern Aegean Sea, Turkey. J. Anim. Vet. Adv., 8: 2537-2541.

Balik, İ. and H. Çubuk, 2001. Sudak (Stizostedion lucioperca (L.)) ve kadife (Tinca tinca (L.)) baliği avciliğinda galsama ağlarinin av verimlerl ve secicilikleri üzerine donam faktörünün etkisi. E. Ü. Su Ürünleri Dergisi, 18: 149-154.

CONSTANT, 1998. GILLNET software. Denmark.

Clarke, J.R., 1960. Report on selectivity of fishing gear. ICNAF Spec. Publ., 2: 27-36.

Fabi, G., M. Sbrana, F. Biagi, F. Grati, I. Leonori and P. Sartor, 2002. Trammel net and gill net selectivity for Lithognathus mormyrus (L., 1758), Diplodus annularis (L., 1758) and Mullus barbatus(L., 1758) in the Adriatic and Ligurian seas. Fish. Res., 54: $375-388$.

Fischer, W. and M. Schneider, 1987. Mediterranean and Black Sea-Fishing Area 37. Volume 1: Plants and Invertebrates, United Nations Food and Agriculture, Rome, Italy.

Fonseca, P., R. Martins, A. Campos and P. Sobral, 2005. Gill-net selectivity off the Portuguese western coast. Fish. Res., 73: 323-339.

Froese, R. and D. Pauly, 2006. Fishbase. World Wide Web Electronic Publication. http://en.wikipedia.org/wiki/ FishBase

Fujimori, Y. and T. Tokai, 2001. Estimation of gillnet selectivity curve by maximum likelihood method. Fish. Sci., 67: 644-654.

Gray, C.A., Jones, M.V. Rotherham, D. Broadhurst, M.K. Johnson and D.D. Barnes, 2005. Utility and efficiency of multi-mesh gill nets and trammel nets for sampling assemblages and populations of estuarine fish. Mar. Freshwater Res., 56: 1077-1088.

Hamley, J.M., 1975. Review of gillnet selectivity. J. Fish. Res. Board Can., 32: 1943-1969.

Holst, R., D. Wileman and N. Madsen, 2002. The effect of twine thickness on the size selectivity and fishing power of Baltic cod gill nets. Fish. Res., 56: $303-312$ 
Holt, S.J., 1963. A method for determining gear selectivity and its application. ICNAF Spec. Publ. Int. Comm. Northwest Atl., 5: 106-115.

Kinacigil, H.T., A.T. Ilkyaz, G. Metin, A. Ulas, O. Soykan, O. Akyol and R. Gurbet, 2008. Balikçilik yönetimi açisindan ege denizi demersal balik stoklarinin ilk ürüme boylari, yaslari ve büyüme parametrelerinin tespiti. TUBITAK-ÇAYDAG Proje Kesin Rapor No. 103Y132: 327s. http://www.ilkyaz.eu/doc/ilkyaz_2008 4.pdf.

Kara, A., 2003. İzmir körfezi'nde İsparoz baliği (Diplodus annularis L., 1758) avciliğinda kullanilan monoflament galsama ağlarin seçiciliğinin araştirilmasi. E. Ü. Su Ürünleri Derg., 20: 129-138.

Karakulak, F.S. and H. Erk, 2008. Gill net and trammel net selectivity in the northern Aegean Sea Turkey. Scientia Marina, 72: 527-540.

Karunasinghe, W.P.N. and M.J.S. Wijeyaratne, 1990. Selectivity estimates for Amblygaster-sirm (Clupeidae) in the small-meshed gill net fishery on the west-coast of Sri-Lanka. Fish. Res., 10: 199-205.

Lucena, F.M. and C.M. O'Brien, 2001. Effects of gear selectivity and different calculation methods on estimating growth parameters of bluefish, Pomatomus saltatrix (Pisces: Pomatomidae), from southern Brazil. Fish. Bull., 99: 432-442.

Madsen, N., R. Holst, D. Wileman and T. Moth-Poulsen, 1999. Size selectivity of sole gill nets fished in the North Sea. Fish. Res., 44: 59-73.

Metin, C., A. Lök and T.A. Ilkyaz, 1998. Fakli göz genisligine sahip dip uzatma aglarinda isparoz (Diplodus annularis Linn., 1758) ve Izmarit (Spicara flexuosa Rafinesque, 1810) Baliklarinin Seçiciligi. Ege Üniversitesi Su Ürünleri Dergisi, 15: 293-303.

Millar, R.B. and R. Holst, 1997. Estimation of gillnet and hook selectivity using log-linear models. ICES J. Mar. Sci., 54: 471-477.

Millar, R.B. and R.J. Fryer, 1999. Estimating the sizeselection curves of towed gears, traps, nets and hooks. Rev. Fish Biol. Fish., 9: 89-116.

Millar, R.B., 1992. Estimating the size-selectivity of fishing gear by conditioning on the total catch. J. Am. Stat. Assoc., 87: 962-968.

Moth-Poulsen, T., 2003. Seasonal variations in selectivity of plaice trammel nets. Fish. Res., 61: 87-94.

Ozekinci, U., 2005. Determination of the selectivity of monofilament gillnets used for catching the annular sea bream (Diplodus annularis L. 1758) by lengthgirth relationships in Izmir Bay (Aegean Sea). Turk. J. Vet. Anim. Sci., 29: 375-380.

Park, C.D., E.C. Jeong, J.K. Shin, H.C. An and Y. Fujimori, 2004. Mesh selectivity of encircling gill net for gizzard shad Konosirus punctatus in the coastal sea of Korea. Fish. Sci., 70: 553-560.
Pet, J.S., C. Pet-Soede and W.L.T. van Densen, 1995. Comparison of methods for the estimation of gillnet selectivity to tilapia, cyprinids and other fish species in a Sri Lanka reservoir. Fish. Res., 24: 141-164.

Petrakis, G. and K.I. Stergiou, 1995. Gill net selectivity for Diplodus-annularis and Mullus-surmuletus in Greek waters, Fish. Res., 21: 455-464.

Petrakis, G. and K.I. Stergiou, 1996. Gill net selectivity for four fish species (Mullus barbatus, Pagellus erythrimus, Pagellus acarne and Spicara flexuosa) in Greek waters. Fish. Res., 27: 17-27.

Prchalova, M., J. Kubecka, M. Riha, T. Mrkvicka and M. Vasek et al., 2009. Size selectivity of standardized multimesh gillnets in sampling coarse European species. Fish. Res., 96: 51-57.

Psuty, I. and W. Borowski, 1997. The selectivity of gill nets to bream (Abramis brama L.) fished in the polish part of the Vistula Lagoon. Fish. Res., 32: 249-261.

Purbayanto, A., S. Akiyama, T. Tokai and T. Arimoto, 2000. Mesh selectivity of a sweeping trammel net for Japanese whiting Sillago japonica. Fisheries Sci., 66: 97-103.

Reis, E.G. and M.G. Pawson, 1992. Determination of gill-net selectivity for bass (Disentrarchus labrax L.) using commercial catch data. Fish. Res., 13: 173-187.

Revill, A., J. Cotter, M. Armstrong, J. Ashworth, R. Forster, G. Caslake and R. Holst, 2007. The selectivity of the gill-nets used to target hake (Merluccius merluccius) in the Cornish and Irish offshore fisheries. Fish. Res., 85: 142-147.

Samaranayaka, A., A. Engas and T. Jorgensen, 1997. Effects of hanging ratio and fishing depth on the catch rates of drifting tuna gillnets in Sri Lankan waters. Fish. Res., 29: 1-12.

Santos, M.M., C.C. Monteiro and K. Erzini, 1995. Aspects of the biology and gillnet selectivity of the axillary seabream (Pagellus-acarne, Risso) and common pandora (Pagellus-erythrinus, Linnaeus) from the Algarve (South Portugal). Fish. Res., 23: 223-236.

Santos, R., 1998. Maturation and gill-net selectivity of two small sea breams (genus Diplodus) from the Algarve coast (South Portugal). Fish. Res., 36: 185-194.

Stergiou, K.I. and K. Erzini, 2002. Comparative fixed gear studies in the Cyclades (Aegean sea): Size selectivity of small-hook longlines and monofilament gill nets. Fish. Res., 58: 25-40.

Stergiou, K.I. and V.S. Karpouzi, 2003. Length-girth relationships for several marine fishes. Fish. Res., 60: 161-168. 
Sulaeman, M., T. Matsuoka and G. Kawamura, 2000. Effect of hang-in ratio on size-selectivity of gillnet. Nippon Suisan Gakkaishi, 66: 439-445.

Van Densen, W.L.T., 1987. Gillnet selectivity to pikeperch, Stizostedion lucioperca (L.) and perch, Perca fluviatilis L., caught mainly wedged. Aquacult. Res., 18: 95-106.
Von Brandt, A., 1975. Enmeshing nets: Gillnets and entangling nets-the theory of their efficiency. EIFAC Tech. Pap., 1: 96-116.

Yokota, K., Y. Fujimori, D. Shiode and T. Tokai, 2001. Effect of thin twine on gill net size-selectivity analyzed with the direct estimation method. Fish. Sci., 67: 851-856. 